\title{
La standardisation de l'inconnu : les protocoles thérapeutiques en cancérologie
}

\section{Ilana Löwy}

\section{(2) OpenEdition}

1 Journals

Édition électronique

URL : https://journals.openedition.org/tc/507

DOI : $10.4000 /$ tc. 507

ISSN : 1952-420X

Éditeur

Éditions de l'EHESS

\section{Édition imprimée}

Date de publication : 1 mars 1996

ISSN : 0248-6016

\section{Référence électronique}

\|lana Löwy, "La standardisation de l'inconnu : les protocoles thérapeutiques en cancérologie »,

Techniques \& Culture [En ligne], 25-26 | 1996, mis en ligne le 28 octobre 2005, consulté le 29 septembre 2022. URL : http://journals.openedition.org/tc/507 ; DOI : https://doi.org/10.4000/tc.507

Ce document a été généré automatiquement le 29 septembre 2022.

Tous droits réservés 


\section{La standardisation de l'inconnu : les protocoles thérapeutiques en cancérologie}

Ilana Löwy 